\title{
Religious Characters and Scientific Achievements through Inquiry Models in Elementary Schools
}

\author{
Yunita Sari ${ }^{1}$, Tutur Wahari ${ }^{2}$, Nuhyal Ulia ${ }^{3}$, Rida Feronika Kusumadewi ${ }^{4}$ \\ Faculty of Teacher Training and Education, Department of Elementary Teacher Education, \\ Sultan Agung Islamic University of Semarang ${ }^{1,3,4}$, SD Negeri Ponowareng ${ }^{2}$ \\ \{yunitasari@unissula.ac.id ${ }^{1}$, tuturwahari@gmail.com², nuhyalulia@unissula.ac.id ${ }^{3}$, \\ ridafkd@unissula.ac.id $\left.{ }^{4}\right\}$
}

\begin{abstract}
The research objective was to improve religious character and science learning achievement through the Inquiri learning model in class III of Ponowareng Public Elementary School. Type of classroom action research. The research subjects were 30 students. Data collection techniques used observation sheets and tests. The results showed that the increase in religious character in the first cycle was $72.30 \%$, and the second cycle was $85.30 \%$, while the increase in learning achievement in science content in the first cycle obtained a completeness percentage of $66.67 \%$ with good criteria. While the second cycle was $86,67 \%$ with very good criteria. From the results of the gain test in cycle I and cycle II showed an increase in syllus 1 of 0.324 and an increase in cycle II of 0.548 , it can be concluded that the inquiry learning model can improve religious character and learning achievement in science content.
\end{abstract}

Keywords: religious character, learning achievement, Science content, Inquiry learning model.

\section{Introduction}

Education is a conscious and planned effort to create an atmosphere of learning and the learning process so that students actively develop their potential to have religious spiritual strength, self-control, personality, intelligence, nation and state. National education functions listed in the Basic Law no. 20 of 2003 Article 3, namely developing the ability and shaping the character and civilization of a nation with dignity in order to educate the nation's life and national education aims to develop the potential of students to become human beings who believe and fear God Almighty, have noble character, are healthy, knowledgeable, competent, creative, independent, and be a democratic and responsible citizen. To achieve the goals of national education, the government has implemented improvements in the quality of education at various types and levels. One of the governments in providing innovation in the national curriculum system is by implementing the 2013 curriculum which emphasizes a competency and character-based curriculum. This curriculum emphasizes the implementation of learning with a thematic approach for elementary school students [1].

The form of the 2013 curriculum at the basic education level uses an integrative thematic system by emphasizing the scientific approach in the teaching and learning process. Integrative thematic learning is a learning approach that integrates various competencies from various subjects into various themes [2].This integrative thematic learning is very promising. 
"The way students learn in the 2013 curriculum is also different from the previous curriculum. Students are required to be more active, creative and innovative in solving problems they face in school "[3].

Learning that emphasizes the cultivation of students' scientific attitudes in the classroom is also in line with the demands of Natural Science content in the implementation of the 2013 curriculum as stated by Susanto in the Ministry of National Education [4] states that "Natural Science learning is based on empowering students to build skills, work scientific knowledge and knowledge that is facilitated by the teacher with a goal-oriented science learning curriculum. One of the goals of the science curriculum in elementary schools is to develop process skills for investigating the environment, solving problems and making decisions ".

However, the reality in the field shows something different. Science learning in schools is still mostly done conventionally. Students should have a scientific attitude that starts from exploring problems through asking as much detail as possible about the various problems described, identifying various information and finding their own ways of solving problems. But the visible fact is that there are still many students who are still not trained in extracting information through questions, still fixated on the old habit of relying only on information available in books and only waiting for directions from the teacher in solving problems, even though some students have shown satisfying scientific attitudes. in the second year of implementing the 2013 curriculum. Things like this indicate that the implementation of the 2013 curriculum at the school level cannot be categorized as maximum and completely successful.

The results of interviews and observations with class III teacher Tutur Wahari showed that the role of students had not appeared to be optimally treated as student subjects who had the potential to develop independently. The position of students is still in a passive learning situation and conditions, teaching and learning activities are still dominated by teachers in conveying information which in general the materials have been written in textbooks. During the learning process the teacher uses the lecture method. Science learning that is applied by the teacher tends to be teacher-centered and students do not carry out the learning process by experiment directly. This will have an impact on student achievement. In addition to the problems in learning, the observation results show that the attitude of students' religious character is still lacking, this is evidenced when praying students do not have an istiqomah attitude in prayer, there are students who say impolite words, still cheating during ulagan, bullying among friends is common. This will have an impact on learning.

Character is the most important thing that must be developed properly and correctly in every young generation. Character is a foundation and the main foundation to be able to fortify yourself from all bad things that are present in the dynamics of life. Octavia [5]. states that in general character is human behavior related to God, self, fellow humans, the environment, and nationality, which is manifested in thoughts, attitudes, feelings, words and actions based on religious norms, laws, manners, culture, and customs. Specifically, character education based on religious values refers to the basic values found in religion (Islam). Character values which are the basic principles of character education are found in several sources, including values that come from the example of the Prophet which are manifested in his daily attitudes and behavior, namely shiddiq (honest), trustworthiness (trustworthiness), tabligh (conveying transparently), fathanah (intelligent)[6]. According to[7], character education programs can be carried out through: teaching, motivation, modeling, habituation, and enforcing rules. These programs can be applied since students are still in elementary school. The implementation of religious character education is in the form of teaching and accustoming children to say assalamualaikum when entering a room, reading prayers, shaking 
hands with teachers, and other activities related to the inculcation of children's religious character values. The provision of religious character values is given in accordance with the abilities and needs of the child. In giving character values, this cannot be done only once or twice, but is done repeatedly and continuously [8].

From the above problems, we need a model that can improve learning achievement of science content and religious character, namely using inquiry learning models. According to [9], "inquiry is a teaching-learning activity in which students are faced with situations or problems to conclude." Furthermore, [10], argues that "the inquiry learning model is a series of learning activities that emphasize critical and analytical thinking processes to seek and find answers to problems by themselves". [11] argues that one of the advantages of the inquiry learning model is that "this approach provides a superior transfer value when compared to other methods." The results of Schlenker's research [12]state that inquiry training can increase understanding of science, and students become skilled in obtaining and analyzing information.

With the application of the inquiry learning model it is hoped that learning is not centered on the teacher and students become active so that it makes learning interesting and challenges students to actively participate in learning. It is also hoped that the application of the inquiry learning model can find their own identity. The purpose of this study is:

a) Improve the religious character of third grade students of Ponowareng State Elementary Schools through inquiry models.

b) Improving the learning achievement of students' science content class III SD Negeri Ponowareng through an inquiry model.

\section{Research Methods}

The type of research used is Classroom Action Research. The Classroom Action Research model used in this study is according to Kemmis and Mc Taggart. Kemmis and Mc Taggart's model explained that in one cycle there are four components, namely planning, acting, observing, and reflecting. The classroom action research design proposed by Kemmis and Mc Taggart [13].

The subjects of this study were 30 grade students of SD Negeri Ponowareng, consisting of 12 male students and 18 female students. Data collection techniques in this study used test and non-test techniques. The test technique is one of the tools to take measurements, namely a tool to collect information on the characteristics of an object. The test is used to find out the student's score after the learning process takes place. The non-test data collection technique was carried out by observation. Research success indicators if:

There is an increase in the religious character of students at at least $85 \%$ of the grades of all students in grade III SD Negeri Ponowareng from cycle I to cycle II.

There is an increase in student achievement in science content, $85 \%$ of all students have scored $\geq 67$. This is based on the Minimum Completeness Criteria Standard in the learning process set at SD Negeri Ponowareng for the subject of Natural Science content

\section{Research Result}

This classroom action research was carried out in two cycles which were carried out by the researcher as the implementer of the action. This classroom action research was carried out in class III SD Negeri Ponowareng using an inquiry learning model in science content. 


\subsection{Cycle 1}

Students are assigned to work on multiple choice questions of 20 questions and the results of the pretest scores can be seen in table 1:

Table 1. Cycle Pretest Value 1

\begin{tabular}{clc}
\hline No & \multicolumn{1}{c}{ Indicator } & information \\
\hline 1 & Total students & 30 \\
2 & KKM (Minimum Completeness Criteria) & 67 \\
3 & Class completeness percentage (success indicator) & $85 \%$ \\
4 & The number of students studied the pretest completely & 14 \\
5 & The number of students did not complete the pretest learning & 16 \\
6 & The number of pretest scores & 1875 \\
7 & Pretest mean score & 62,50 \\
8 & Percentage of posttest completeness & $46 \%$ \\
\hline
\end{tabular}

Based on the table above, it is known that the pretest score is low, it is proven that there are still many students who have not yet completed the Minimum Completion Criteria, namely 67.The pretest results show that the class average score is 62.50 and the percentage of completeness is $46 \%$ with the lowest score of 30 and the highest score is 75 . Of the 30 students, it is known that there are only 14 students who have fulfilled the Minimum Completion Criteria, while 16 students have not met the Minimum Completion Criteria. Observation sheet of religious characters observed during the learning process, namely from the beginning of class to finish learning. The results of observations of the religious character of student learning can be explained in table 2:

Table 2. Observation Results of Religious Character Cycle 1

\begin{tabular}{cccc}
\hline No & indicator & percentage & information \\
\hline 1 & Pray & $74 \%$ & good \\
2 & Dress politely and neatly & $73 \%$ & good \\
3 & Speak kind and polite & $70 \%$ & good \\
\hline \multicolumn{4}{c}{} \\
& Total & $\mathbf{2 1 7}$ & \\
& Percentage & $\mathbf{7 2 , 3 0 \%}$ & good \\
\hline
\end{tabular}

Data regarding the posttest scores were obtained from the posttest question sheets which were carried out by students at the end of the lesson after the implementation of science learning. Students are assigned to work on multiple choice questions of 20 questions and the results of the posttest scores can be seen in table 3:

Table 3 Cycle Posttest Value I

\begin{tabular}{clc}
\hline No & \multicolumn{1}{c}{ indicator } & information \\
\hline 1 & Total students & 30 \\
2 & KKM (Minimum Completeness Criteria) & 67 \\
3 & Class completeness percentage (success indicator) & $85 \%$ \\
4 & The number of students studied the pretest completely & 19 \\
5 & The number of students did not complete the pretest learning & 11 \\
6 & The number of pretest scores & 2240 \\
7 & Pretest mean score & 75
\end{tabular}




\begin{tabular}{crc}
\hline No & indicator & information \\
\hline 8 & Percentage of posttest completeness & $66,67 \%$ \\
\hline
\end{tabular}

Based on the table above, namely the results of the posttest cycle I meeting 2 with an average value of 75 with a percentage of completeness of $66.67 \%$ of the total students, so that it does not meet the indicators of research success, namely at least $85 \%$ of student learning completeness. Data regarding the normalized gain test were obtained from the results of the pretest and posttest that were carried out in cycle I. The results of the calculation of the normalized gain test in cycle I can be seen in table 4 .

Table 4. Normalized Gain Test Results in Cycle I

\begin{tabular}{clc}
\hline No & Value & $\begin{array}{c}\text { Score } \\
\text { Cycle I }\end{array}$ \\
\hline 1 & Pretest & 1870 \\
2 & Posttest & 2240 \\
\hline & Total & 0,324 \\
& Criteria & medium \\
\hline
\end{tabular}

\subsection{Cycle II}

Data regarding the pretest scores were obtained from the pretest question sheets that were done by students at the beginning of learning before the implementation of learning can be seen in table 5:

Table 5. Cycle Pretest Value II

\begin{tabular}{clc}
\hline No & \multicolumn{1}{c}{ indicator } & information \\
\hline 1 & Total students & 30 \\
2 & KKM (Minimum Completeness Criteria) & 67 \\
3 & Class completeness percentage (success indicator) & $85 \%$ \\
4 & The number of students studied the pretest completely & 22 \\
5 & The number of students did not complete the pretest learning & 8 \\
6 & The number of pretest scores & 2180 \\
7 & Pretest mean score & 72,66 \\
8 & Percentage of posttest completeness & $73,33 \%$ \\
\hline
\end{tabular}

Based on the table above, it is known that the pretest score is still low, it is proven that there are still many students who have not yet completed the Minimum Completion Criteria (KKM), namely 67.The pretest results show that the class average score is 72.66 and the percentage of completeness is $73.33 \%$. the lowest score is 30 and the highest score is 75 . Of the 30 students, it is known that only 22 students have met the KKM, while 8 students have not. Observations of students' religious character were obtained from the observation sheets that were observed during the learning process, namely from the beginning of class to the completion of learning. The results of observations of students' religious character can be explained in table 6 :

Table 6. Observation results of religious character cycle II

\begin{tabular}{|c|c|c|c|}
\hline No & indicator & percentage & information \\
\hline 1 & Pray & $86 \%$ & very good \\
\hline 2 & Dress politely and neatly & $85 \%$ & very good \\
\hline
\end{tabular}




\begin{tabular}{|c|c|c|c|}
\hline No & indicator & percentage & information \\
\hline 3 & Speak kind and polite & $85 \%$ & very good \\
\hline & total & 256 & \\
\hline & Percentage & $\begin{array}{c}85,30 \% \\
\text { very good }\end{array}$ & \\
\hline
\end{tabular}

Based on the table above, the observation results of students' religious character in the implementation of learning through the inquiry learning model with an average indicator of $85 \%$ with very good criteria. Data regarding student learning achievement were obtained from posttest question sheets that were carried out after the learning process using the inquiry learning model. The results of cycle II student learning scores as measured by student posttest sheets can be explained in table 7 :

Table 7. Cycle Posttest Value II

\begin{tabular}{clc}
\hline No & \multicolumn{1}{c}{ Indicator } & information \\
\hline 1 & Total students & 30 \\
2 & KKM (Minimum Completeness Criteria) & 67 \\
3 & Class completeness percentage (success indicator) & $85 \%$ \\
4 & The number of students studied the pretest completely & 26 \\
5 & The number of students did not complete the pretest learning & 4 \\
6 & The number of pretest scores & 2630 \\
7 & Pretest mean score & 87,67 \\
8 & Percentage of posttest completeness & $86,67 \%$ \\
\hline
\end{tabular}

Based on the table above, it is known that the pretest score is still low, it is proven that there are still many students who have not completed the Minimum Completion Criteria (KKM), namely 67.The postest results show that the class average score is 87.67 and the percentage of completeness is $86.67 \%$. that 26 students who have fulfilled the KKM, while those who have not met the KKM are 4 students. Data regarding the normalized gain test were obtained from the pretest and posttest results that were carried out in cycle II. The results of the calculation of the normalized gain test in cycle II can be seen in table 8 :

Table 8. Normalized Gain Test Results in Cycle II

\begin{tabular}{clcc}
\hline \multirow{2}{*}{ No } & & Value & $\begin{array}{c}\text { Score } \\
\text { Cycle II }\end{array}$ \\
\hline 1 & Pretest & 2180 \\
2 & Posttest & 2630 \\
\hline & Total & 0,548 \\
& Criteria & Medium \\
\hline
\end{tabular}

Based on the table above, the normalized gain test results in cycle II reached a total of 0.548 and included in the moderate interpretation criteria. Based on the results of research on the religious character of students using the inquiry learning model in cycle I and cycle II have increased. In cycle 1, the number was 217 with a percentage of $72.30 \%$ in good category and an increase in the second cycle with a number of 256 with a percentage of $85.30 \%$ The results of student achievement in the normalized gain test in the first cycle were 0.324 and the second cycle increased by 0.548 . It can be concluded that the inquiry learning model can improve religious character and science learning achievement in grade III SDN Ponowareng students. This is supported by research conducted [14] that there are differences in scientific attitudes and science learning outcomes between students who take guided inquiry learning models and 
students who follow conventional learning models in grade IV SD Negeri students in Kaliuntu village. The scientific attitude and science learning outcomes of learning with guided inquiry learning models are better than groups of students who learn with conventional learning models. Likewise research [15] the application of inquiry learning models can improve science learning outcomes, in the material of the nature and changes of objects in grade IV SD No. 5 Rolls for the 2016/2017 school year. This can be seen from the classical completeness of student learning outcomes in the first cycle reached an average of $70 \%$ and the percentage was categorized as $72.75 \%$, while in cycle II the percentage of classical completeness of learning outcomes was $90 \%$. cycle II which is equal to $20 \%$.

\section{Conclusion}

Based on the results of classroom action research that has been carried out for two cycles in an effort to improve religious character and learning achievement of science content through inquiry learning models for grade III students of SDN Ponowareng, it can be concluded:

a) Learning using the inquiry learning model can improve religious character. Based on the observations, the results obtained in the first cycle with a total of 217 with a percentage of $72.30 \%$ with good criteria. Whereas in cycle II the number was 256 with a percentage of $85.30 \%$ with very good criteria.

b) Learning using the inquiry learning model can improve student achievement in science content. Student learning achievement in science content can be seen from the completeness of student learning in cycle I obtained pretest scores with an average of 62.50 with a percentage of $46 \%$ and posttest scores with an average of 75 and a percentage of completeness of $66.67 \%$, then in the second cycle of meetings 1 increases with the obtained pretest value with 72.66 with a percentage of $73.33 \%$ completeness. At the second meeting, the posttest score was obtained with an average of 87.67 and a percentage of completeness of $86.67 \%$, with very good criteria.

\section{References}

[1] Octaviani, S.: Pengembangan bahan ajar tematik dalam implementasi kurikulum 2013 kelas 1 sekolah dasar. Edu Humaniora Jurnal Pendidikan Dasar Kampus Cibiru, 9(2), 93-98. 9( 2017)

[2] Husamah dan Yanur : Desain Pembelajaran Berbasis PencapaianKompetensi Panduan Merancang Pembelajaran untuk Mendukung Implemntasi Kurikulum 2013. Jakarta. : Prestasi Pustaka Jaya. (2013)

[3] Kurniasih dan Berlin.: Kurikulum 2013. Jakarta: Rajawali Pers (2014)

[4] Susanto, Ahmad : Teori Belajar dan Pembelajaran di Sekolah Dasar. Jakarta: Kencana Prenada Media Group (2006)

[5] Oktavia, A. S: Pendidikan Antikorupsi Bagi Siswa Sekolah Dasar di Kecamatan Gunung Pati, Jurnal Universitas PGRI Semarang, 4 (2): 11-17. (2014)

[6] Hidayatullah, M. Furqon : Pendidikan Karakter: Membangun Peradaban Bangsa. Surakarta: Yuma Pustaka. (2010)

[7] Syarbini, A : Model Pendidikan Karakter dalam Keluarga. Jakarta: Gramedia. (2017) 
[8] Atika, S : Pelaksanaan pendidikan karakter (religius, cinta tanah air dan disiplin) di SLB Al Ishlaah Padang. Jurnal Penelitian Pendidikan Khusus, 3(3). (2014)

[9] Setyanto, A: Panduan Sukses Komunikasi Belajar Mengajar. Jogjakarta: Diva Press.(2014)

[10] Hamdayama, J:Model dan Metode Pembelajaran Kreatif dan Berkarakter. Bogor: Ghalia Indonesia. (2014)

[11] Ngalimun: Strategi dan Model Pembelajaran. Yogyakarta: Aswaja Pressindo(2016)

[12] Trianto : Model-Model Pembelajaran Inovatif Berorientasi Konstruktivistik. Jakarta: Prestasi Pustaka. (2007)

[13] Paizaluddin dan Ermalinda : Penelitian Tindakan Kelas. Bandung: Alfabeta.(2016)

[14] Dewi, N. L., Dantes, N., \& Sadia, I. W. (2013). Pengaruh model pembelajaran inkuiri terbimbing terhadap sikap ilmiah dan hasil belajar IPA (Doctoral dissertation, Ganesha University of Education). (2016)

[15] Juniati, N. W., \& Widiana, I. W: Penerapan Model Pembelajaran Inkuiri Untuk Meningkatkan Hasil Belajar IPA. Jurnal Ilmiah Sekolah Dasar, 1(1), 20-29.(2017) 